\title{
Effective EFL Teachers as Viewed by Senior High School Students
}

\author{
Ulfah Alfiyyah Abu \\ ualfiyyah@yahoo.co.id \\ Abdul Halim \\ abdhalimmhum@yahoo.com \\ Graduate Program, \\ State University of Makassar, Indonesia
}

\begin{abstract}
This research aimed to investigate the characteristics of effective EFL teachers as viewed by the students and various characteristics of effective EFL teachers as viewed by the different students' English achievement. This research was designed by using qualitative research. This research applied purposive sampling technique. The participants of this research were two classes of SMA Negeri 17 Makassar in the academic year 2015/2016. The data was collected through class discussion and individual interview. The results of this research suggest that EFL teachers are need to focus on 15 characteristics indicated effective EFL teachers based on government rules (Permendiknas number 16/2007) which are placed into four categories, they are pedagogical, personal, professional, and social competences and in addition, teachers need to improve their academic qualification, pay attention to physical appearance, and adopt the characteristics of younger and female teachers as the most favored by the students. Furthermore, the different students' achievement affects their view of various characteristics of effective EFL teachers covering assessment and evaluation, learning process, the use of social media, what should be understood, and appearance.
\end{abstract}

Keywords: Effective EFL Teacher, Favorite teacher, Teachers' Competence, EFL Classroom

\section{INTRODUCTION}

This article reports a study of the characteristics of effective EFL teachers as viewed by students. A basic assumption here is English is one of the subjects which are not anticipated by most students. The students worry if they pronounce words which are not in accordance with the correct pronunciation, especially when the teacher directly pointed the student to talk. Furthermore, they also do not know the meaning of a lot of English vocabulary which make them difficult to understand a text. The one that must be responsible in this case is the teacher. What students learn depends on how they are taught (Kennedy, 1997: 3). This statement shows that the method used by teachers in teaching delivers important information to students about the subject matter. How the subject taught tells students whether the subject is interesting or boring, understandable or poorly understandable, applied or theoretical, and relevant or irrelevant. The Minister Regulation of National Education (Peraturan Menteri Pendidikan Nasional Republik Indonesia/ Permendiknas) number 16 (2007), the requirement for the teachers are having academic qualification, competence, teaching certificate, good condition and mental, and ability to achieve goals of the national education. 
Teacher effectiveness has been an ongoing topic of interest among educational researchers for many years, with considerable focus given to the specific traits and behaviors that are believed to constitute effective teaching. There are many strategies to create an effective teaching, but the successful teaching of each teacher is determined by their own strategies (Richards, 2001: 209). An effective teacher can compensate for deficiencies in curriculum, materials, or resources used in teaching. The present research considers the characteristics of EFL teachers that can support the successful of teaching and learning process.

Fifteen (15) characteristics of effective teachers are placed into three categories, they are instructional techniques, classroom management, and personal traits (Park \& Lee: 2006). Firstly, Instructional techniques mean the English teachers should be knowledgeable of grammar, vocabulary, writing, literary elements, great novels, researching techniques, speech strategies, etc. in teaching the English skills. The English teacher must be flexible and try some teaching strategies. Secondly, an effective English teacher is good at classroom management. The last is personality traits. It is very important that students feel caring by their teachers and it is important to be able to laugh and to keep going since students need a happy teacher instead of an angry one.

This research was intended to answer two questions:

(1) What are the characteristics of effective EFL teachers as viewed by the students?

(2) What are the different views of different students' English achievement regarding characteristics of effective EFL teachers?

The result of this research was expected to give the theoretical and practical contribution to the teaching English as a foreign language in Indonesian context.

\section{LITERATURE REVIEW}

\section{Teacher qualification and competence}

The interpretation of the quality of teachers in this context relies on the assumption that teachers with well-established qualifications will give high-quality instruction. Roberts (1998) in Richard (2001: 209) mentions the core components of teacher qualification, they are practical knowledge, content knowledge, contextual knowledge, pedagogical competence, personal knowledge, and reflective knowledge. Those qualifications are not much different in Indonesia, as the Minister Regulation of National Education (Peraturan Menteri Pendidikan Nasional Republik Indonesia/Permendiknas) number 16 (2007) had arranged standard academic qualifications and competence of teachers. The academic qualifications for Senior High School teachers or equivalent must have a minimum education qualification of Diploma (D-IV) or a bachelor degree (S1) study program in accordance with the subjects that are taught and was obtained from an accredited institution. Teacher competence includes pedagogical competence, personal competence, social competence, and professional competence.

\section{Effective EFL teachers}

Some scholars in language education have conducted studies to identify the characteristics of EFL teachers in different contexts. Celik et al (2013) have successfully 
identified the characteristics of an effective EFL teacher in Turkish context. Similarly, Pettis (1997: 68) identifies three main characteristics for a professionally competent teacher: principle-based, knowledgeable, and skillful. Borg (2006: 3) examines the definitions of over 200 practicing and prospective English language teachers between various language teachers and other subjects. It is found that the methodology of English teaching is more progressive than other subjects, consequently, English teachers should be more up-to-date to overcome the advanced and progressive nature of the methodology of language teaching. English teachers are also supposed to have a closer, more relaxed, and more positive relationship with the students compared with other teachers.

Dewey (1960) in Knowles (1990:87) states all of the education comes from experience. The problem in teaching is selecting the kinds of present experiences that have a benefit for other new experiences. Other concept is interaction. This theory indicates that educators should provide activities to students who can make them acquire and develop new experience by interacting with the society, such as engaging in an organization where students can contribute something useful. According to Tuan (2012), motivation has an important role in enhancing the students in English learning activities. Students were motivated both of intrinsic and extrinsic motivation. Since the teachers know the essential of motivation, they organized and applied various motivational activities in English classroom.

\section{METHOD}

The research was designed by using qualitative research. The explanation of the research results were made in descriptive. The students of SMAN 17 Makassar are the population of this research. The sample was selected based on purposive sampling technique. The researcher chose the students of two classes in class X and XI taught by different English teachers. The samples of this research were 72 students. The samples to be interviewed were selected based on their English achievement.

The data were collected through interview. There were 20 questions related to effective EFL teachers and terms of teacher competences. Interview is divided into two steps. The first step, the researcher conducted class discussion for students in a class and asked them based on the prepared interview guide. The class discussion lasted from 40-50 minutes. The second step, the researcher interviewed 12 selected students who got the highest, average, and low English achievement to answer the second research question. Each interview lasted from 9-23 minutes.

\section{RESULTS}

This presents the findings of qualitative analysis of interview transcripts to answer the research questions as previously stated in the introduction.

\section{Pedagogical Competence}

\section{Understanding students well}

There are three aspects that must be considered, they are the characteristics should be understood by EFL teachers, identify students' learning potential and identify students' difficulties related to English learning. Students have a different learning style as one of student stated, "...willing to listen to the students. So, the teacher can see from different 
points of view. He/she did not see from his/her own perspective but he/she understands students' learning style since every student has a different learning style."

In addition, teacher should know the students' potential toward the subject matter. According to the students, their teachers need to check the students understanding, whether the students can do the task or need more explanation or not, if the students need more explanation, it is better to explain individually, not for all of students. Another aspect, teachers must know students who already speak English well and vice versa.

Furthermore, teachers should identify students' difficulties related to English learning. It is shown by the student, "Teachers also need to know the problem of students in learning, for example, whether the lessons are easy to understand or not."

\section{Teaching strategies related to the students' need}

The students were interested in learning English by the implementation of various approaches, strategies, methods, and teaching techniques creatively by the teacher. Being a teacher who is favored by the students is one thing indicating the teacher is an effective teacher. As a students described about her favorite English teacher, "She is very enjoyable and she knows students' ability well, everything about the students so it makes us never get bored. I am very pleasant." The students also mentioned that effective teachers should be creative in designing the teaching method in order students would get bored.

Student stated after delivering the materials in lecture method, it is better to give the task. Another thing that the students mentioned the most on the interview is games. The teachers need to provide various games in teaching and learning process to make the students interested to learn English. Besides that, teachers also need to arouse the sense of togetherness of the students by working in group. Furthermore, there is a need for an intermezzo to make the students relax and not boring. At that time, the teacher could share about their experience, information about the school or his/her personal life, joke and motivation.

\section{Preparing the suitable syllabus for students}

Before teaching, teachers need to prepare the syllabus. On the syllabus, the teachers arranged the learning materials based on the appropriate approach and students' needs. The students proposed the teachers teach the students from basic to the higher level. It means that the teachers need to explain clearly the current materials before moving to the next materials and ensure that language used can be understood by the students because it's a foreign language, so as the students who are new to English study, it is difficult to understand. One student commented, "...the teacher should know the suitable material for the students so that they can learn easily, and sometimes the teacher uses the language that is unsuitable for the students' level, so the students feel lazy to study because they think that the material is difficult and unsuitable with their level."

\section{Learning by experience and instructional media}

As stated by a student, once a month or once in two months, his teacher is preparing for outdoor learning by meeting the foreigner. It is also suggested for the teacher to use instructional media and learning resources which are relevant to the subject matter for 
example using presentation, playing music, film and after that students learn based on those media. As experienced by the student, if there is free class, their English teacher invited them to come to the laboratory for watching English movie and asking the students what the movie is about.

\section{Using information and communication technology}

Using information and communication technology (ICT) is one aspect that makes the students more interested in the teaching and learning process. It becomes something primary from tertiary. ICT can be the most effective media based on all sources as stated by the student. The teachers need to know how to use and operate all of those kinds of information and communication technology tools which can support the quality of learning outcomes. So if the teacher want to make a power point they will not asking for the students help. But, sometimes the teacher used power point with full paragraph that makes students asleep. It is better to adding the video or audio.

\section{Actualizing the students' skill}

The students mentioned that ideal teachers should encourage the students to actualize their skill. The students proposed the example; teachers engage all of students to speak. It could be by using games or something else. One example from other student, her teacher applied English full in his classroom. So, during the learning process it is a must for students to speak English. If there are any students do not speak English, they will be punished as one student revealed, "...the teachers have to make all of their students to speak up. Maybe the teacher can try something to make students more enthusiasts to speak maybe for example by using games or something else."

\section{Having a social media as a media of communication}

The students were really happy when they are having a good communication with their teacher. They talk not only in the classroom but also outside the classroom. Social media become one of the tools to provide the communication between the students and the teacher as some students perceived they were become friend with their teacher on Facebook and Path account. By having a good communication, when students were given a task, they can ask the teacher about that without any doubt. So teachers should be able to interact with the students and well understand the students.

\section{Assessing and evaluating students}

The students' final score is not only come from the last final but also considered that assignment is the best choice to determine students' achievement. As some students proposed, it can be seen from the daily assignment, whether the students submit their assignment, how far the students' progress, because test just once, maybe at that time the students unwell and their score is down, in fact they could do better. And it is too bad giving too many assignments. The students proposed some examples of assignment could be given for example assignment which encourages students' creativity.

\section{Personal Competence}


This section deals to show the students' perception on their linguistic self-confidence in using English, showing good nature, being honest, friendly, kind, patient, mature, wise, and discipline person.

\section{Social Competence}

Communicating with students and students' parent

The teacher also should communicate effectively, emphatically, and politely to the students. As the student mentioned teachers have to be polite and treat students objectively and indiscriminative. It is also expected to establish a good communication to students' parents therefore parents can control their children by contact the teacher to get information about their children's progress in school.

\section{Professional Competence}

\section{Mastering the materials of the subject taught}

Teacher must be having knowledge about various aspects of English and having command in spoken and written English. As the students stated the most important is teacher must be able to speak English and master the materials. Teachers also need to learn how to delivers the materials well.

\section{Creative learning materials}

Teachers should select teaching and learning materials in accordance with the level of students. As students stated that English is a foreign language, so as the students who newly study English, it's difficult to understand. It should begin from the basic in stage to make the student easily to understand.

\section{Academic qualification related to the teachers' teaching}

Some students stated that they do not want to be taught by teachers who have academic qualification of doctoral (S3). They think the language used by those teachers is not suitable with the senior high school students' comprehension so the students will not understand what teachers said. So, they think D3 and S1 are appropriate enough. While some students prefer English teachers have qualifications beyond the standard, the main aspect is their teaching experience. They said that an Effective EFL teacher should be had a minimal learning experience for three years. Different responses from some students, they said it is important for the teacher having a standard qualification, because it will be affect to their teaching. Teachers should be smart to answer all of students' questions well.

\section{Physical appearance related to the students' motivation in learning}

Physical appearance could motivate students in learning but it is also distract students' attention in learning. If there is something wrong with the teacher's appearance, it could be interested the student's attention to their teacher appearance not with the material as mentioned by the student. If the teacher is good looking and neat, the students feel interested to see their teacher. The teacher should not untidy and dirty. It is proven by one 
student stated, "the first, the teacher should be neat, the hair should be brushed before teaching."

\section{Age related to the teachers' characteristics}

The students argued that younger teachers understand the students more than the older teachers. The older teachers were easy to get mad, sensitive, less enthusiastic and having many rules which are hate by students. It is also considered that the functions of their body were reduced hearing function and memory function.

\section{Female teachers vs male teachers}

Most of the students prefer female teacher to male teacher. Female teacher is understands more on the students' character. The students feel free to share about everything that they cannot do to the male teacher. They were not shy and afraid to ask about something to teacher because they are in the same gender. In other opinion, female teacher is more motherhood. Students said female teacher was more flexible, objective and indiscriminative to all students. Male teacher is more subjective and discriminative. Some students also prefer male teachers than female teachers. It is because male teacher is more humorists. Moreover, male teachers are usually more inclined to logic while female teachers are usually more inclined to feelings. There are some students a bit shy to talk with female so they prefer male teachers.

\section{DISCUSSION}

\section{The characteristics of effective EFL teachers}

Pedagogical competence is one of the competencies which have a major influence on the teaching and learning process. First aspect, teachers need to understand the students' characteristic to make the suitable materials to the students. It can be seen in picture 1 .

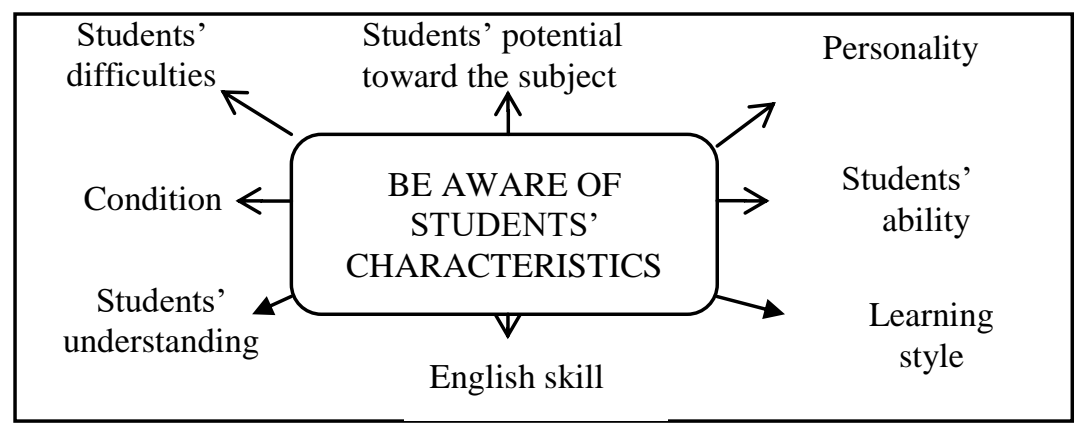

\section{Picture 1 Be Aware of Students' Characteristics}

As shown in the picture 1, the teachers need to know the students' personality and ability to treat them in different ways. The students has a different learning style, they are visual, auditory, and kinesthetic. The teachers need to know their students learning style in order that teachers could combine all the learning styles in learning process. It is a must to identify the students' difficulties and potential toward the subject matter to make the students' progress. 
Secondly, how teachers should deliver the materials to the students. It can be seen in the picture 2 .

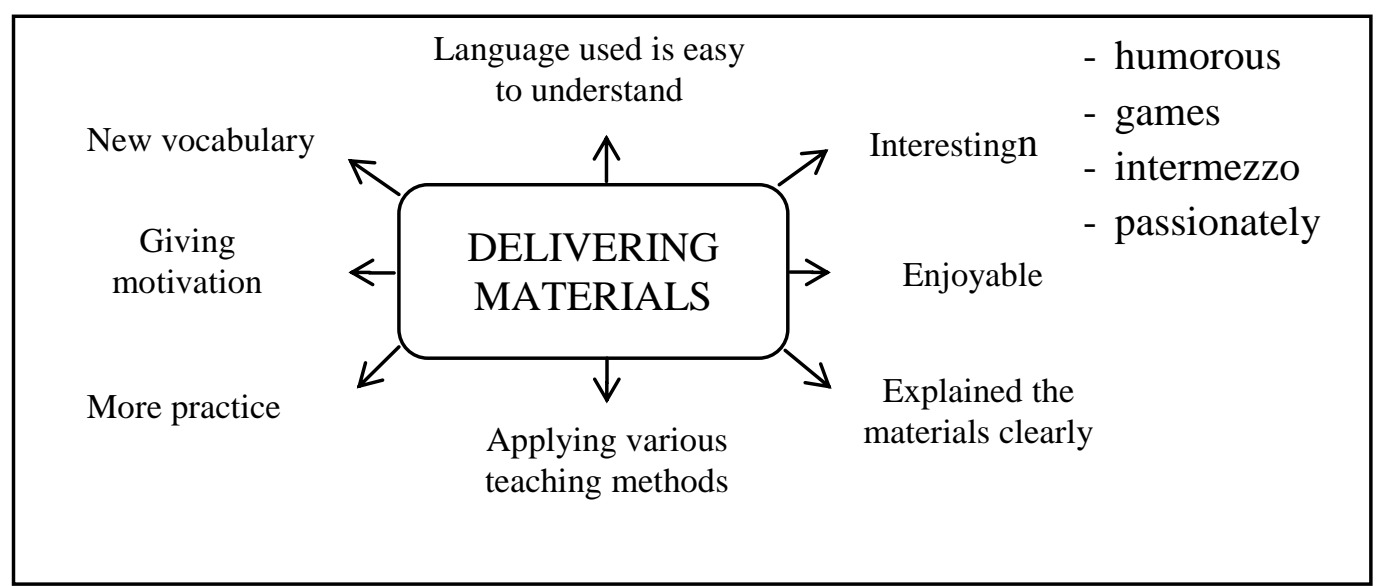

Picture 2 Delivering Materials

There is a need having ability in choosing appropriate teaching strategies and ability to organize learning activities on the development of standards in the preparation of EFL teacher as stated by Kalebic (2005) in Shishavan \& Sadeghi (2009: 132). The students mentioned that effective teachers should be creative in designing the teaching method. They need to apply various teaching method in teaching and learning process so teachers have to cover all of them.

Another thing that the students most mentioned on the interview is games. Harmer (1998: 1-3) mentions some qualities which good teachers possess is an ability to give interesting classes games to make students are more interested to learn English. However, they have to vary the games that can be applied in teaching and learning process so the students will not be bored.

As noted by Celik, et al. (2013), an effective EFL teacher can be categorized the one who has a sound knowledge of vocabulary, teaches pronunciation well, adapt at providing explanations in mother tongue. Pronunciation is important as explained by the students that students will imitate what the teacher pronounce. When the teachers' pronunciation was wrong, students also would be wrong, but if the teachers' pronunciation was correct, students would pronounce it correctly. Therefore in teaching and learning process, it is not recommended to use English only because some students are having low vocabulary mastery.

Teachers required for having ability to motivate learners for learning (Kalebic, 2005 in Shishavan \& Sadeghi, 2009: 132). Motivation is a supporting form of teachers to force the students in learning English. As the students mentioned his favorite teacher, his teacher is the one who has a good method in teaching, he always give motivation for students to warm them up in studying English so the students were motivated in studying English.

Teachers need to prepare the syllabus. On the syllabus, the teachers arranged the learning materials based on the appropriate approach and students' need. The students proposed 
the teachers to teach the students from basic to the higher level, teachers need to explain clearly the current materials before moving to the next materials and uses language that is suitable for the students' level. Related to the subject of this research, the students need a lot of vocabulary, so they agree if the English teacher gives new vocabulary in every meeting to increase their vocabulary mastery. It is shown in picture 3 .

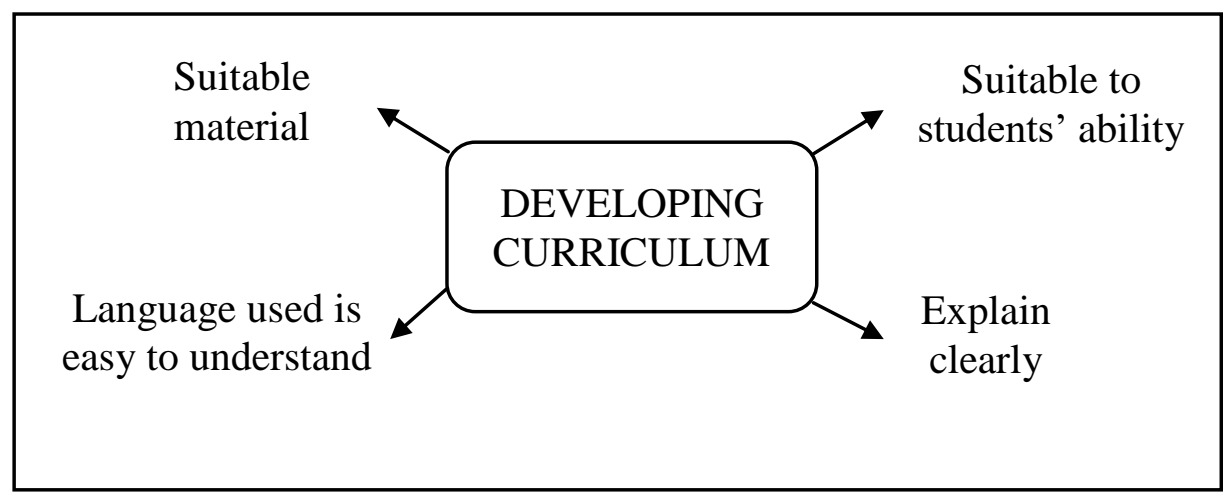

Picture 3 Preparing the Suitable Syllabus for Students

Teaching and learning process is not only conducted in the classroom but also outside the classroom. Teachers also may use instructional media and learning resources which are relevant to achieve the learning objectives as seen in picture 4 .

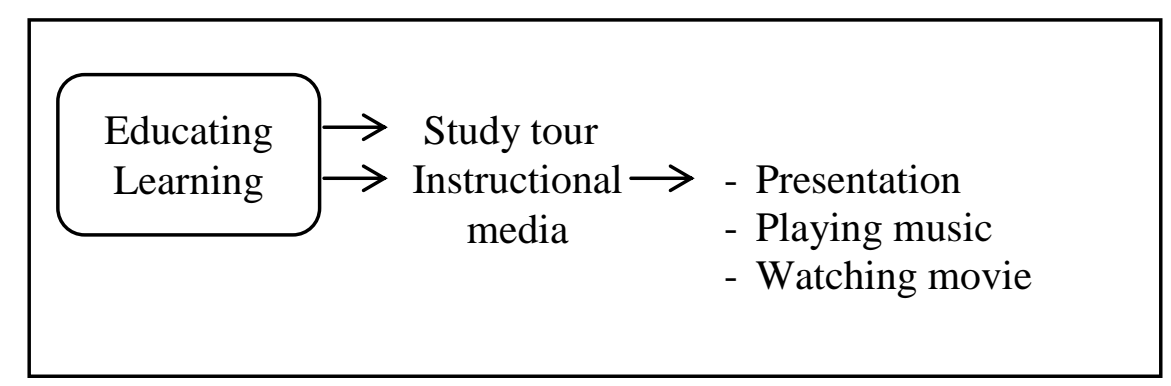

Picture 4 Conducting and Educating Learning

One mentioned by the student that his teacher always brings him and his classmate to meet the foreigners once in two months. The students allowed speaking English with foreigners. It is related to Deweys' system (1960) in Knowles (1990:87). Deweys' system is organized around several key concepts. The central concept is experience. This theory indicates that educators should provide activities to students who can make them acquire and develop new experience by interacting with the society.

The recent years, learning is not only supported in classroom, textbooks and between teacher and students but it also utilizes the presence of information and communication technology as used in the school as in the picture 5 . 


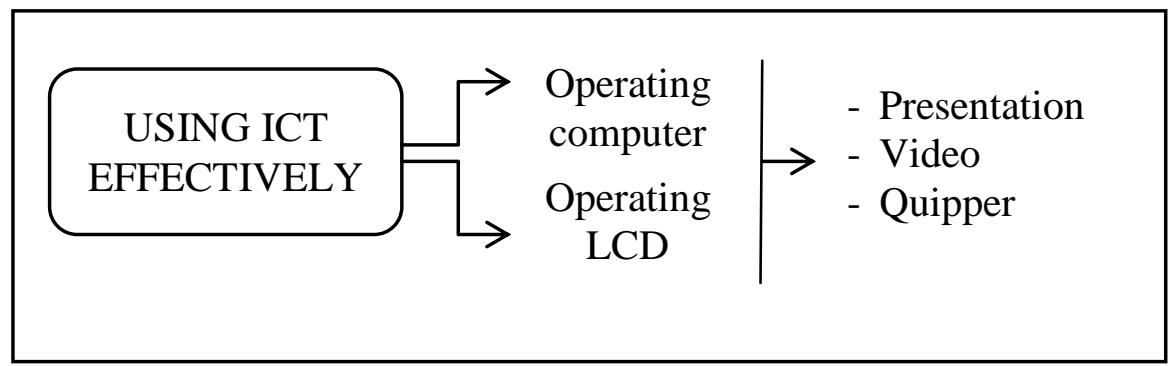

Picture 5 Using ICT Effectively

Information and communication technology are usually used by the teachers such as computer and LCD to help them explaining the materials by power point presentation. Honestly, material on the power point did not attract the attention of students because they were not a point, but such a long sentence or paragraph so that students feel bored. Teachers should provide a keyword in each sentence or make it shorter, make it in chart, add animated image and video.

The progressive development of computer-mediated communication, online forum has developed into more engaged in classroom settings to promote critical thinking of the student, knowledge edifice and language learning autonomy (Wang, 2004: 272). According to Picciano (2002:1), online forums are one of the simplest tools of computermediated communication that teachers can easily combine their teaching to extend discussions beyond classroom contexts. This online forum is also used by the teachers, it is called Quipper. The teachers were utilized it to upload the assignment and test. The questions were multiple choices. Students know directly their score after completing the assignment and the correct answer to each question would be appear. In order to offer a successful learning, teachers need to be fully skilled in practical use of the sites.

One of qualification of an ideal teacher is having a good communication with students. It is proved by the current findings, the teachers need having a good communication with the students. It can be seen in the picture 6 .

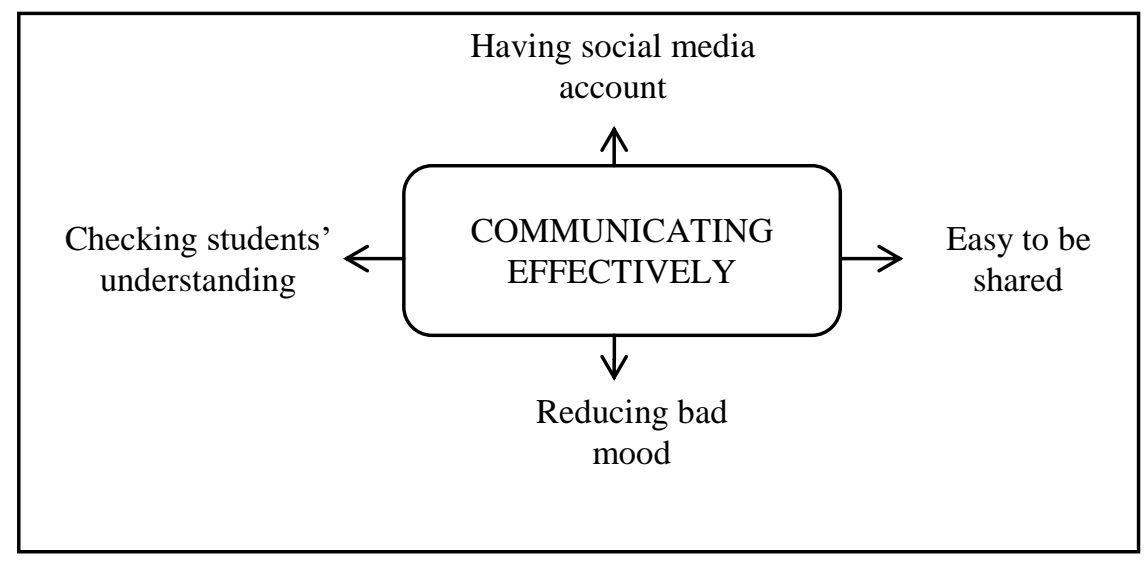

Picture 6 Communicating Effectively

Social media become one of the tools to provide the communication between the students and the teacher. The students presumed to be exist when their teacher always give chance 
to their students to communicate with in social media such as Facebook, Twitter, and Path. Students did not feel awkward and feel free to ask about the assignment they do not understand or even just have a comment on the status posting by the teachers in social media. The teacher may exploit the use of social media as a learning media for example engage student to use English in written form. Furthermore, teachers need to reduce their bad mood when talking with the students in order students will not be awkward to ask or share with teachers.

Assessment and evaluation is process to know the students understanding about the materials taught. There are three kinds will be accumulated in this process as seen in the picture 7 .

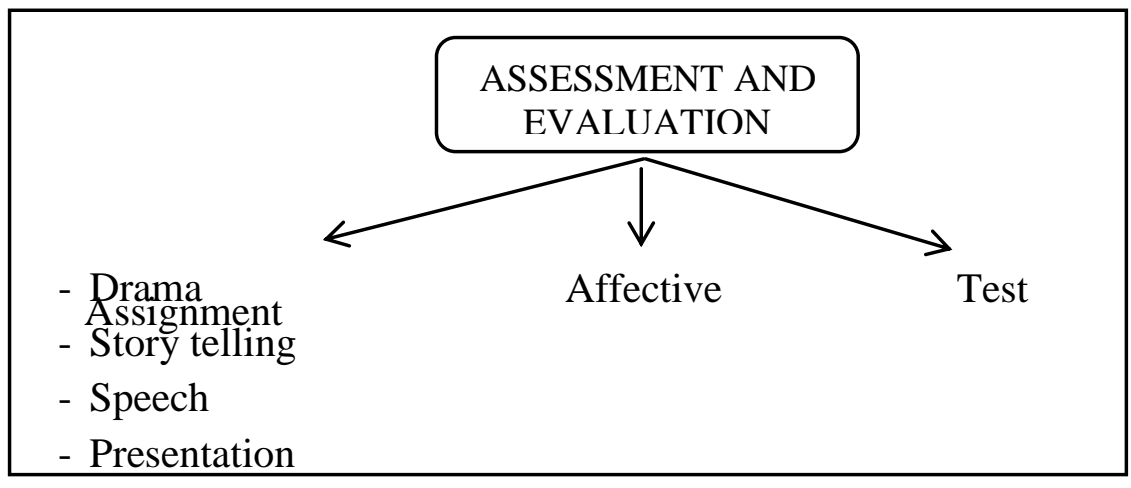

Picture 7 Assessment and Evaluation

These processes should be conducted fair and interesting. There are three aspects in accumulating the students' score, firstly assignment, secondly affective, and the last test. Assignment has a high percentage for students because the students have done a lot of assignment and they really focus on it. The students proposed that interesting assignment such as drama, storytelling, speech, and presentation because that assignment directly involves the students' skills, besides improving English skills, especially speaking ability but also the students' creativity. Test was not fair because some of students were cheating.

Teachers' personal competence is also a very important role as viewed of the students such as friendly, kind, patient and discipline.

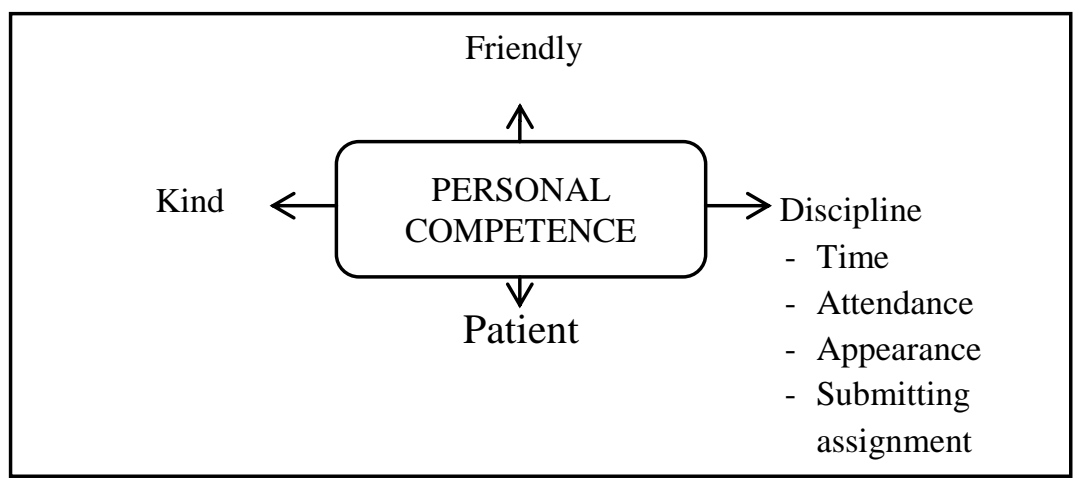

Picture 8 Teachers' Personal Competence 
Being friendly with the students, teachers are easier to know the students' characteristics and having a good communication with the students. The closer the relationship between teachers and students, the teacher is getting easier to know the emotional state of the students. It is easier to provide instruction to students in the learning process.

One of the fourteen competencies required by language teachers on the standard development in the Preparation of Foreign Language Teacher (Kalebic, 2005 in Shishavan \& Sadeghi, 2009: 132) is maintain discipline. Related to this research, there are four aspects of discipline mentioned by the students, discipline of time, appearance, attendance, and submitting assignment. If those disciplines are violated, there is punishment. The punishment is given to create deterrent effect to the offender to not to do it again.

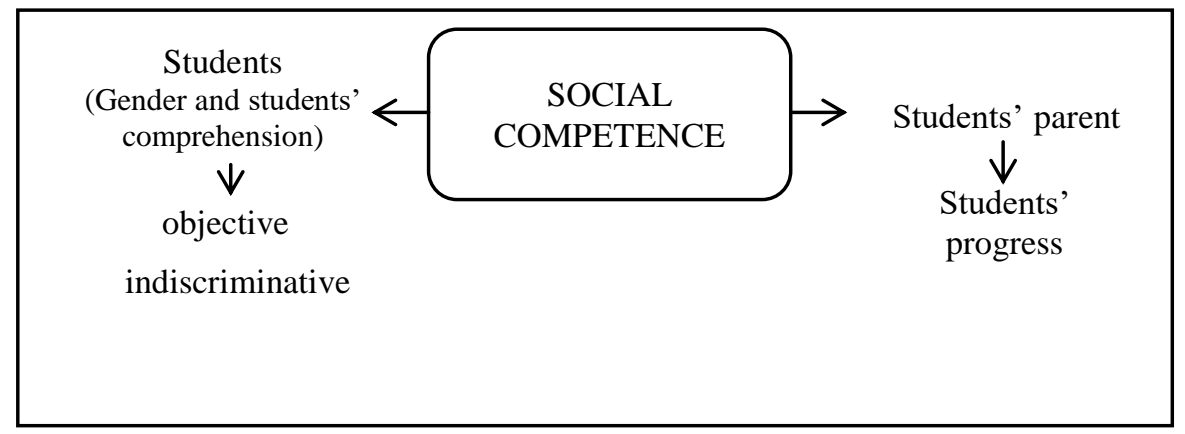

Picture 9 Communicating Effectively between Teacher and Students and Students' Parent

The teacher also should communicate effectively, emphatically, and politely to the students. As the student mentioned teachers have to be polite and treat students objectively and indiscriminative. Sometimes, teachers only pay attention to the smart students. It is also expected to establish a good communication to students' parents therefore parents can control their children by contact the teacher to get information about their children's progress in school.

Pettis (1997: 68) mentions an effective teacher must be personally committed to his/her professional development. The things should be done are mastering the material of the subject taught, developing the learning materials creatively, and developing their own professionalism as can be seen in the picture 10 .

Mastering the material, the structure, and the concept of the subject taught

$\uparrow$

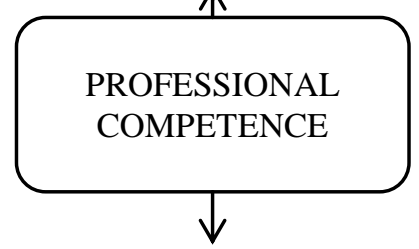

Selecting teaching and learning materials in accordance with the level students<smiles>CC[Te]</smiles>

- Linguistics

- Discourse

- Sociolinguistics

- Strategies

Picture 10 Professional Competence 
The students proposed the teacher must be able to speak English, mastering the materials, do not make the students sleepy during teaching and learning process, and build up the student's enthusiasm. Teacher must be having knowledge about various aspects of English. The English teachers for senior high school or equivalent must have a minimum education qualification of Diploma (D-IV) or a bachelor degree (S1) study program in accordance with the subjects that are taught and was obtained from an accredited institution. Some students prefer effective EFL teachers are having academic qualification more than the standards. In contrast, some students ignored having teachers who have academic qualification more than the standards.

The age related to teachers' characteristics. It has an influence on the learning process. The students proposed effective EFL teachers are twenty five to forty years old. The younger teachers are easier to understand the students' characteristics so it was easier for them to delivers the materials to the students. The students argued that the older teachers were easy to get mad, sensitive, less enthusiastic and having many rules which are hate by students. It is also considered that the hearing functions and the memory function were reduced.

\section{Different views of different students' achievement regarding characteristics of effective EFL teachers}

Based on the result of the interview of the high, medium and low achiever, there were some similar and different characteristics found by the researcher. All of the students wanted the enjoyable environment in the teaching and learning process. They wanted their teachers to deliver material in interesting way, utilize the information and communication technology effectively, have a good pronunciation, and have a good sense of humor.

The differences were put on some aspects. The first aspect is assessment and evaluation. All of students agreed assignment being the main aspect in given final score but students wanted different ways to be given assignment. In one hand, the high achiever students wanted the assignment in the form of oral so the teachers know who are good at pronunciation, who are really memorize a given assignment, and there is no cheating. In addition, teachers should be seen from activeness of the students in the classroom. In the other hand, the low achiever students wanted group working in order the high achiever students helping the low achiever. They also wanted teachers could give more score to the low achiever who has great attitude.

In the process of English teaching and learning, the high achiever students were not satisfy when they were asking to the teacher then the teacher inquired to other students to discuss about that question, they did not satisfy to their other friends' answer while the low achiever students sometimes ask to their friends if they did not understand the materials. Furthermore, the high achiever students wanted more practice than explanation while the low achiever students wanted more and clearly explanation before giving assignment, and they did not like too much assignment.

Some of high achiever students felt being friends with the teacher in social media is not too important but some students, mostly the medium and low achiever students felt happy being friends with the teacher in social media. They said they would be enjoyed interacting with their teachers and feel free to ask and share anything. The low achiever 
students like friendly teachers so that they are more interested to learn because there is an emotional connection that exists.

The high achiever students would be understood in terms of their learning style. For the low achiever students, beside their learning style, they would be understood in terms of their intellectual, prior knowledge, difficulties in the subject matter and their problems which lead to their lack of attention in learning.

The last, physical appearance related to the motivation of students in learning. The high achievers were not really notice for teacher's appearance. Teachers' fashion must be shown as an educator. In the other hand, physical appearance could motivate the lower achiever students in learning but it is also distract students' attention in learning. The teacher should be fashionable, good looking, and neat. If the teacher is untidy, the students feel not enjoyable to study.

\section{CONCLUSION}

Related to the findings and discussion, it can be concluded that there are 15 characteristics indicated effective EFL teachers based on government rules (Permendiknas number 16/2007) which are placed into four categories, they are pedagogical, personal, professional, and social competences, and in addition teachers need improving their academic qualification, pay attention to physical appearance, and adopt the characteristics of younger and female teachers as the most favored by the students. Furthermore, the different students' achievement have different views regarding characteristics of effective EFL teachers covering assessment and evaluation, learning process, the use of social media, what should be understood, and appearance.

\section{SUGGESTION}

Based on the conclusion, the researcher proposed some suggestions as follows:

1. The results of this research would be the reference for EFL teachers to have and apply those characteristics in effective teaching.

2. It is suggested to policy maker in assessing the teachers' professionalism and teacher certification to consider the characteristics of effective English teacher which have been found in this research.

\section{REFERENCES}

Borg, S. 2006. The Distinctive Characteristics of Foreign Language Teachers. Language Teaching Research, 10(1), 3-31.

Celik, S., Arikan, A, \& Caner, M. 2013. In the Eyes of Turkish EFL Learners: What Makes an Effective Foreign Language Teacher? Porta Linguarum 20, 287-297.

Harmer, J. 1998. How to Teach English: An Introduction to the Practice of English Language Teaching. England: Addison Wesley Longman Limited.

Kennedy, M. M. 1997. Defining an Ideal Teacher Education Program (Online), (http://www.ncate.org/). 
Knowles, M. S. 1990. The Adult Learner: A Negleted Species. Houston, London, Paris, Zurich, Tokyo: Gulf Publishing Company.

Park, G. \& Lee, H. 2006. The Characteristics of Effective English Teachers as Perceived by High School Teachers and Students in Korea. Asia Pacific Education Review, 7(2), 236-248.

Peraturan Menteri Pendidikan Nasional Republik Indonesia Nomor 16. 2007. Standar Kualifikasi Akademik dan Kompetensi Guru.

Pettis, J. 1997. Developing our Professional Competence: Some Reflections. TESL Canada Journal, (Online), 14(2) (http://www.teslcanadajournal.ca/index.php/tesl/article/view/686/517).

Picciano, A. G. 2002. Beyond Student Perceptions: Issues of Interaction, Presence, and Performance in an Online Course. Journal of Asynchronous Learning Networks, 6(1): 21-40.

Richards, J. C. 2001. Curriculum Development in Language Teaching. Cambridge, United Kingdom: Cambridge University Press.

Shishavan, H. B. \& Sadeghi, K. 2009. Characteristics of an Effective English Language Teacher as Perceived by Iranian Teachers and Learners of English. Canadian Center of Science and Education, (Online), 2(4), (www.ccsenet.org/journal.html)

Tuan, L.T. 2012. An Empirical Research into EFL Learners' Motivation. Theory and Practice in Language Studies, 2(3), 430-439.

Wang, Q. \& Huay, L. W. 2007. Comparing Asynchronous Online Discussions and Faceto-Face Discussions in a Classroom Setting. British Journal of Educational Technology, 38(2), 272-286. 